\title{
Survey on heavy metals contaminated soils in Thai Nguyen and Hung Yen provinces in Northern Vietnam
}

\author{
Khảo sát đất ô nhiễm kim loại nặng ở tỉnh Thái Nguyên và tỉnh Hung Yên \\ thuộc miền Bắc Việt Nam
}

Research article

Chu, Thi Thu Ha*

Institute of Ecology and Biological Resources, Vietnam Academy of Science and Technology, 18 Hoang Quoc Viet, Hanoi, Vietnam

\begin{abstract}
In Vietnam, soil contamination with lead and cadmium at very high level was investigated and discovered in the surrounding areas of zinc-lead mining and processing factory in Tan Long (Dong Hy district, Thai Nguyen province) and around the lead-recycling smelter in Chi Dao (Van Lam district, Hung Yen province). The survey on soil contaminated by arsenic due to the tin mining and sifting activities in Ha Thuong (Dai Tu district, Thai Nguyen province) was also carried out. In Tan Long, the concentrations of lead and cadmium in the old solid waste dump from zinc-lead factory varied from 1,100 to $13,000 \mathrm{mg} \cdot \mathrm{kg}^{-1}$, and from 11.34 to $61.04 \mathrm{mg} \cdot \mathrm{kg}^{-1}$, respectively. Soil Pollution Indexes (SPI) of lead and cadmium were highest in the old solid waste dump area, followed by the ones in the rice paddy soils. In Chi Dao, the soils of many sites were polluted with lead and cadmium such as in the gardens of lead-recycling households where the concentrations of lead and cadmium were $7,000-15,000 \mathrm{mg} \cdot \mathrm{kg}^{-1}$ and $1.8-3.6 \mathrm{mg} \cdot \mathrm{kg}^{-1}$. In rice paddies, the soils were also polluted by lead. SPI of lead in paddy soil areas within $300 \mathrm{~m}$ radius from the lead smelter were from 3.6 to 100 fold higher than the safe limit. The sediment from the ditch near the lead smelters contained extremely high levels of lead $\left(7,000-110,000 \mathrm{mg} \cdot \mathrm{kg}^{-1}\right)$ and cadmium $(3.8$ - $17.7 \mathrm{mg} \cdot \mathrm{kg}^{-1}$ ). The tin mining and sifting activities in Ha Thuong was the cause for the arsenic contamination of the soil in this area. The arsenic contents in soils at all locations investigated were higher than $320 \mathrm{mg} \cdot \mathrm{kg}^{-1}$ (dry weight) and up to $3,809 \mathrm{mg} \cdot \mathrm{kg}^{-1}$.
\end{abstract}

Tại Việt Nam, đất bị ô nhiếm bởi chì và ca-đi-mi với hàm luợng cao đã được điều tra phát hiện ở các khu vưc phu cận của nhà máy khai thác và chế biến kẽm/chì thuộc địa phận xã Tân Long, huyện Đồng Hỷ, tỉnh Thái Nguyên và các khu vục phu cận của lò tái chế chì thuộc địa phận xã Chỉ Đạo, huyện Văn Lâm, tỉnh Hung Yên. Sụ khảo sát đất bị ô nhiễm bởi a-sen do các hoạt động khai thác và tuyển thiếc ở xã Hà Thuợng, huyện Đại Tù̀, tỉnh Thái Nguyên cũng đã được tiến hành. Tại xã Tân Long, nồng độ chì và ca-đi-mi trong bãi chất thải rắn cũ tù nhà máy sản xuất kẽm chì là $1.100-1.300 \mathrm{mg} \cdot \mathrm{kg}^{-1}$ và tù 11,34 đến 61,04 mg. $\mathrm{kg}^{-1}$, tuoong ứng. Chỉ số ô nhiếm đất (SPI) của chi và ca-đi-mi cao nhất trong khu vục đổ chất thái rắn cũ, tiếp theo sau là ở các ruộng lúa. Tại xã Chỉ Đạo, đất ở nhiều địa điểm đã bị ô nhiếm chì và ca-đi-mi chẳng hạn nhu trong khu vuờn của các hộ gia đình tái chế chì, nồng độ chì và ca-đi-mi là $7.000-15.000 \mathrm{mg} \cdot \mathrm{kg}^{-1}$ và 1,8 - 3,6 mg. $\mathrm{kg}^{-1}$. Trong cánh đồng lúa, đất cũng bị ô nhiếm bởi chì Chỉ số ô nhiễm đất của chì (SPI-Pb) trong cánh đồng lúa trong vòng bán kính $300 \mathrm{~m}$ tù lò tái chế chì cao hơn giới hạn của đất an toàn tù̀ 3,6 đến 100 lần. Trầm tích thu tì̀ kênh gần lò tái chế chì chứa hàm lương chì rất cao $(.7000-110.000$ $\left.m g \cdot \mathrm{kg}^{-1}\right)$ và ca-đi-mi $\left(3,8-17,7 \mathrm{mg} \cdot \mathrm{kg}^{-1}\right)$. Việc khai thác và tuyển thiếc tại xã Hà Thuợng đã gây ra ô nhiếm a-sen trong đất tại khu vục này. Hàm luợng a-sen trong đất tại tất cả các địa điểm nghiên cúu cao hon $320 \mathrm{mg}^{\mathrm{kg}}{ }^{-1}$ (trọng lượng khô), đặc biệt là lên đến $3809 \mathrm{mg} . \mathrm{kg}^{-1}$.

Keywords: heavy metal, metal mining, lead recycling, soil pollution, Thai Nguyen, Hung Yen 


\section{Introduction}

Heavy metals contamination of soils has become one of the most serious environmental problems today. The sources of heavy metals in those soils are diverse, including burning of fossil fuels, mining and smelting of metalliferous ores, municipal wastes, fertilisers, pesticides, sewage sludge amendments and the use of pigments and batteries. Some of the heavy metals are micronutrients necessary for plant growth, such as $\mathrm{Zn}$, $\mathrm{Cu}, \mathrm{Mn}, \mathrm{Ni}$ and $\mathrm{Co}$, while others have no known function, such as $\mathrm{Cd}, \mathrm{Pb}$ and As.

Due to their immutable nature, these heavy metals are a group of pollutants of much concern. Once heavy metals penetrate into the food chain, they can damage the health and life of animals and human because of their toxicities. Lead $(\mathrm{Pb})$ is a kind of heavy metal with neuro-virulent properties that animals and human are very sensitive to. The toxic effect of $\mathrm{Pb}$ is mainly based on its ability to react with functional groups such as sulfhydryl, carboxyl and amine, leading to a decrease or loss of activity of many enzymes that are important for cell functions (Peng et al., 2005). People living around $\mathrm{Pb}-\mathrm{Zn}$ mining areas in Thai Nguyen province of Vietnam occurred some sign of heavy metal poisoning even cancer disease (Gia Lai Online, 2011). And in a lead recycling village in Hung Yen province of Vietnam, a lot of children became less intelligent than the children in other places of this province (Viet Bao, 2011).

Cadmium (Cd) is an occupational and environmental pollutant implied in the development of various types of cancer. It is carcinogenic in animals under certain exposure conditions and may enhance the occurrence of lung and possibly of prostate cancer in workers exposed to high airborne concentrations (Lawerys et al., 1990). In fact, there were a lot of people poisoned by $\mathrm{Cd}$ (several deaths were also reported) in cases such as the $\mathrm{Cd}$ pollution in Toyama prefecture, Japan, in 1955 (Fleischer et al., 1974). The disease was epidemic among elderly women who gave birth to many children. The outstanding features of the disease were lumbar pain and myalgia, spontaneous fractures with skeleton deformation.

Arsenic (As) is a highly bioactive and toxic element, its presence at elevated levels in soils and drinking water being threatening food safety and human health. It adversely affects biological activities as a teratogen, carcinogen or mutagen as well as having detrimental effects on the digestive system, respiratory system and immune system (Sun et al., 2007). In Vietnam, arsenic caused some people have pain and injury in heart, lung, even death in the case of a 7 year-old child in 2001 (VnExpress, 2011). Inorganic arsenic (arsenate and arsenite) is highly toxic to plants because it uncouples phosphorylation and inhibits phosphate uptake. At higher concentrations, arsenic interferes with plant metabolic processes and can inhibit growth and under severe conditions may lead to plant's death (Geng et al., 2006).

\subsection{Study area}

Thai Nguyen and Hung Yen are two provinces located in the north of Vietnam and near Hanoi (Figure 1).

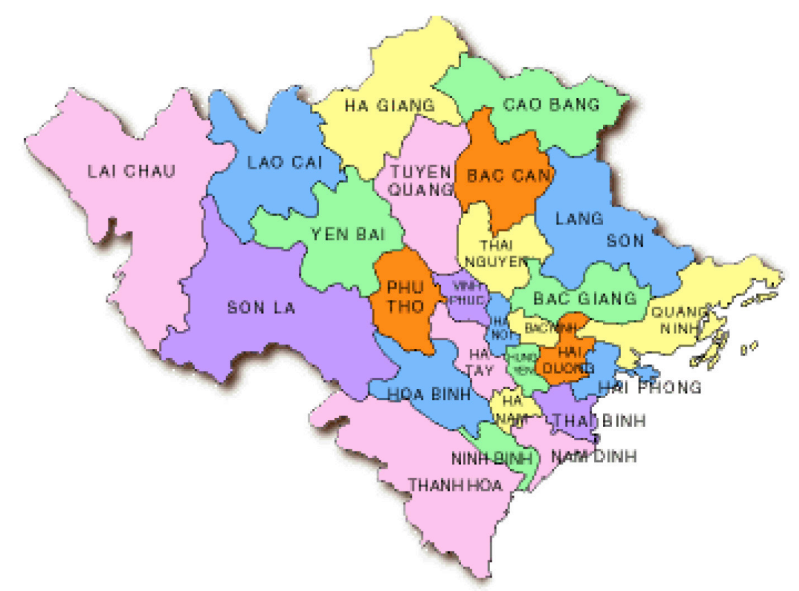

Figure 1. Location of Thai Nguyen and Hung Yen provinces

The $\mathrm{Zn} / \mathrm{Pb}$ mining operation areas in Tan Long (Dong Hy district, Thai Nguyen province), $\mathrm{Pb}$ smelter areas in $\mathrm{Chi}$ Dao (Van Lam district, Hung Yen province) and Snmining operation areas in Ha Thuong (Dai Tu district, Thai Nguyen province) of Vietnam are the places focused on for investigating the $\mathrm{Pb}, \mathrm{Cd}$, As contents in soils.

Tan Long is the place where a former $\mathrm{Zn} / \mathrm{Pb}$ mining and processing French factory operated in the early of $20^{\text {th }}$ century. After 1954, the activities were ceased but since 1980 , they were re-started. The disposal of the waste from mining and processing of heavy metals caused $\mathrm{Cd}$ and $\mathrm{Pb}$ pollution in the surrounding environment (Figure 2).

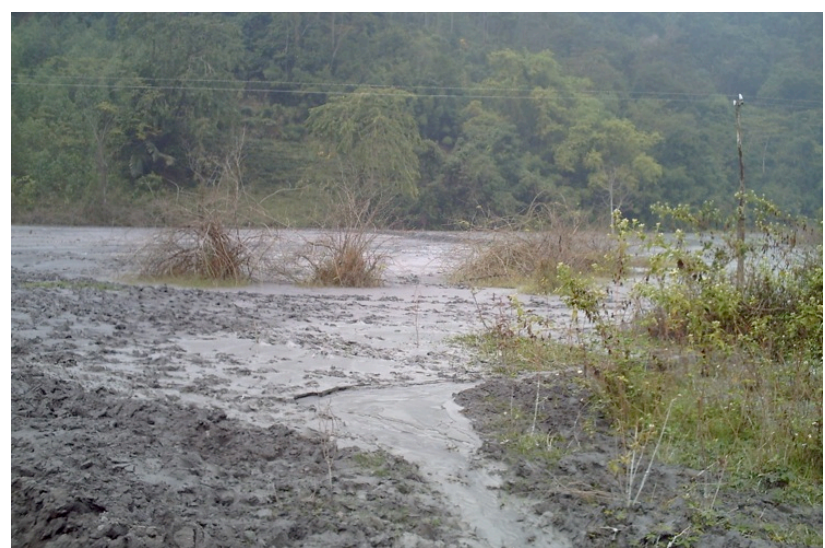

Figure 2. The new waste dump disposed by the $\mathrm{Zn} / \mathrm{Pb}$ factory in Tan Long

Chi Dao is the village whose population dealt with the $\mathrm{Pb}$-recycling since 1978 up to now. The people collected many old batteries to take the $\mathrm{Pb}$ for the recycling process (Figure 3). $\mathrm{Pb}$ and $\mathrm{Cd}$ from the smelters was eliminated into atmosphere, soil and water and might have effects on the vegetable and rice products of the area.

\section{Location, materials and methods}




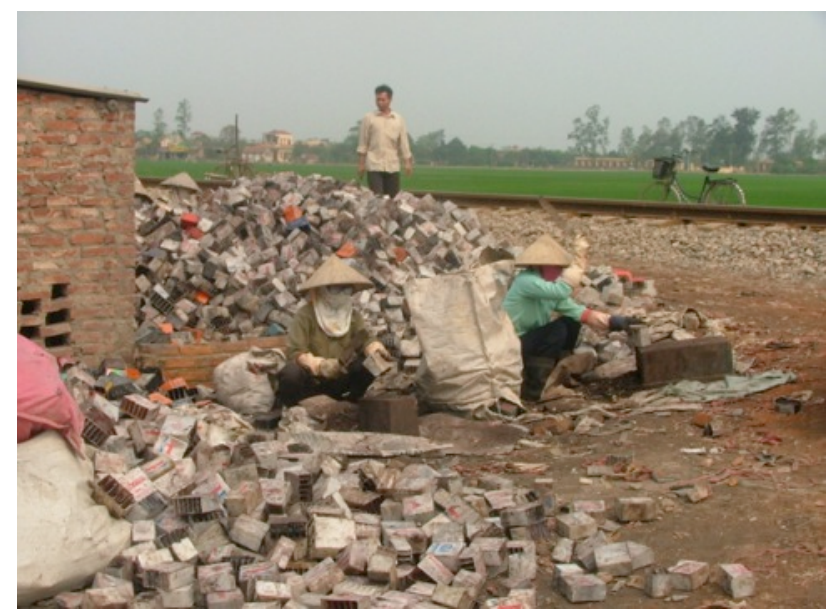

Figure 3. Collection of old batteries in Chi Dao

Ha Thuong is the place where the Sn-ore mining and sifting activities led to the As contamination in ground water and soil of the local areas.

\subsection{Materials and methods}

Soil samples were collected at the surface zone within 0 $20 \mathrm{~cm}$. They were air-dried at room temperature for $5-7$ days. The large-size debris, stones and pebbles were removed, then the soil was grinded and sieved through a 2 $\mathrm{mm}$ polyethylene sieve. The mineralization of samples was done with $\mathrm{HNO}_{3}$ 65\% (Merck-Germany) and some droplets of $\mathrm{H}_{2} \mathrm{O}_{2}$ at $100-110^{\circ} \mathrm{C}$. The $\mathrm{Pb}$ and $\mathrm{Cd}$ contents were analyzed by dithizone and Atom Absorption Spectroscopy (AAS) methods. The As content was analyzed by AAS method.

The accuracy of the analysis process is controlled by blank, duplication and reference samples (Tort-2 of Canada). The heavy metal pollution levels in soil are assessed by the Soil Pollution Indexes (SPI):

$$
\text { SPI }=\frac{\text { Heavy metal content in study soil }}{\text { Safe level }(\text { Vietnam standard })} \times 100
$$

SPI $<100$ : bellow the pollution level; $\mathrm{SPI}=100$ : safe level; SPI>100: pollution level.

\section{Results and discussion}

\subsection{Soil pollution in Tan Long}

At the site near the $\mathrm{Zn} / \mathrm{Pb}$ mining and processing factory in Tan Long, solid wastes of ore-sifting operation are going through gutter to the dumps near the factory. The source of heavy metal pollution in soil is the wastewater and the solid wastes of ore-sifting activities, as well as the dust from ore grinding, transportation and storing. There are two waste dump areas: the old one on the way to the factory (abundant long time ago) and the new one which is about $1 \mathrm{~km}$ far from the factory which several years ago received the waste flow of the factory daily (Figure 2).
For assessing the pollution level of interested heavy metals in this area, hundreds of soil samples were collected and analyzed. The analysis results of the soil samples collected at six main sites are shown in Table $\mathbf{1 .}$ For the site containing old waste dump, $\mathrm{Pb}$ and $\mathrm{Cd}$ contents were the highest $\left(1,100-13,000 \mathrm{mg} \cdot \mathrm{kg}^{-1}\right.$ and $11.34-61.04 \mathrm{mg} \cdot \mathrm{kg}^{-1}$, respectively). This was followed by the new waste dump area with concentrations of $\mathrm{Pb}$ and $\mathrm{Cd}$ ranging from $5,300-9,200 \mathrm{mg} \cdot \mathrm{kg}^{-1}$ and $5.90-$ $9.05 \mathrm{mg} \cdot \mathrm{kg}^{-1}$, respectively. In the paddy soils, the concentrations of $\mathrm{Pb}$ and $\mathrm{Cd}$ were 1,271 - 3,953 $\mathrm{mg} \cdot \mathrm{kg}^{-1}$ and $2.30-42.90 \mathrm{mg} \cdot \mathrm{kg}^{-1}$. The garden soils near the new waste dump had contents of $\mathrm{Pb}$ and $\mathrm{Cd}$ at the lowest levels (27.9 - $35.8 \mathrm{mg} \cdot \mathrm{kg}^{-1}$ and $0.08-0.12 \mathrm{mg} \cdot \mathrm{kg}^{-1}$, respectively). The garden soils near the old waste dump had the $\mathrm{Pb}$ content of all study sites and the $\mathrm{Cd}$ content of some collected samples higher than the safe levels recommended by the Vietnam standard 7209:2002 $(\mathrm{Pb}$ : $230-360 \mathrm{mg} \cdot \mathrm{kg}^{-1}$ in comparison with $70 \mathrm{mg} \cdot \mathrm{kg}^{-1}$ and $\mathrm{Cd}$ : 0.6 - $3.4 \mathrm{mg} \cdot \mathrm{kg}^{-1}$ in comparison with $2.0 \mathrm{mg} \cdot \mathrm{kg}^{-1}$ ).

Concerning the Soil Pollution Indexes (SPI), the SPI values of $\mathrm{Pb}$ and $\mathrm{Cd}$ in the soil of old waste dump were: 1,570 - 18,570 and 570 - 3,050, respectively. These results showed that the soils in the old waste dump had the $\mathrm{Pb}$ content exceeding the safe level from 15.7 to 185.7 times, and the $\mathrm{Cd}$ content exceeding the safe level from 5.7 to 30.5 times (Vietnam standard).

In the paddy soils near the old waste dump, the SPI of Pb and $\mathrm{Cd}$ were 1,810 - 5,650 and 115 - 2,150. In the garden soils near the old waste dump, the SPI of $\mathrm{Pb}$ and $\mathrm{Cd}$ were $390-510$ and $30-170$, higher than the safe levels for $\mathrm{Pb}$ by $3.9-5.1$ fold, and in some samples, the concentrations of $\mathrm{Cd}$ exceeded the safe level by up to 1.7 fold. The amount of heavy metals in the soils at this area mainly originated from the residues accumulated long time ago and from precipitations since this waste dump no longer received the waste from the $\mathrm{Zn} / \mathrm{Pb}$ factory. The soils near the new waste dump had the SPI-Pb of 230 to 1,290 , exceeding the safe level by $2.3-12.9$ times. However, the soils were not polluted by Cd (SPI-Cd: 6 - 70).

The garden soils near the new waste dump were just slightly contaminated by these two heavy metals with very low SPI values (SPI-Pb: 40 - 50, SPI-Cd: 4 - 6). These low indexes proved that the background soils in this area were very poor in $\mathrm{Pb}$ and $\mathrm{Cd}$. The waste of $\mathrm{Zn} / \mathrm{Pb}$ factory contained a large amount of $\mathrm{Pb}$ and $\mathrm{Cd}$, this being the source of toxic heavy metal pollution that needed to be controlled. From the new waster dump of the $\mathrm{Zn} / \mathrm{Pb}$ factory, the heavy metals were eliminated every day and this led to the $\mathrm{Pb}$ and $\mathrm{Cd}$ contamination of the adjacent soil areas at higher level than in garden soils. Thus, in Tan Long, around the $\mathrm{Zn} / \mathrm{Pb}$ factory, soils were polluted by $\mathrm{Pb}$ and $\mathrm{Cd}$ due to the mining activities, the old waste dump area had a higher pollution level than the new waste dump. 
Table 1. Contents in soils and SPI of Pb and Cd at study sites in Tan Long (Dang et al., 2007; Dang et al., 2008)

\begin{tabular}{|c|c|c|c|c|c|}
\hline \multirow{2}{*}{$\mathbf{N}^{0}$} & \multirow{2}{*}{ Sites } & \multicolumn{2}{|c|}{ Contents (dry weight, $\mathrm{mg} \cdot \mathrm{kg}^{-1}$ ) } & \multicolumn{2}{|c|}{ Soil Pollution Indexes (SPI) } \\
\hline & & $\mathbf{P b}$ & Cd & $\mathbf{P b}$ & Cd \\
\hline 1 & New waste dump & $5,300-9,200$ & $5.90-9.05$ & - & - \\
\hline 2 & Soil area adjacent to the new waste dump & $164-904$ & $0.12-1.42$ & $230-1290$ & $6-70$ \\
\hline 3 & Garden soils near the new waste dump & $27.9-35.8$ & $0.08-0.12$ & $40-50$ & $4-6$ \\
\hline 4 & The old waste dump & $1,100-13,000$ & $11.34-61.04$ & $1,570-18,570$ & $570-3,050$ \\
\hline 5 & Paddy soils adjacent to the old waste dump & $1,271-3,953$ & $2.30-42.90$ & $1,810-5,650$ & $115-2,150$ \\
\hline 6 & Garden soils near the old waste dump & $230-360$ & $0.6-3.4$ & $390-510$ & $30-170$ \\
\hline 7 & Vietnam standard 7209:2002 & 70 & 2.0 & 100 & 100 \\
\hline
\end{tabular}

\subsection{Soil pollution in Chi Dao}

In Chi Dao, Pb-recycling activities have been operated since 1978 at many households in the village and at the centralized smelter area in the paddy field near the road. The $\mathrm{Pb}$ was released into soil from three main sources: wastewater of the battery breaking, solid waste and dust smoke of recycling processes.

Table 2 shows that, in the village, the garden soils of $\mathrm{Pb}$ recycling households contained $\mathrm{Pb}$ and $\mathrm{Cd}$ concentrations $\left(7,000\right.$ - $15,000 \mathrm{mg} \cdot \mathrm{kg}^{-1}$ and 1.8 - $3.6 \mathrm{mg} \cdot \mathrm{kg}^{-1}$, respectively) much higher than the garden soils of the household that were not affected by $\mathrm{Pb}$-recycling activities (40 - 60 and $0.5-0.8 \mathrm{mg} \cdot \mathrm{kg}^{-1}$, respectively). In the paddy field, the $\mathrm{Pb}$ and $\mathrm{Cd}$ contents in the soil less than $20 \mathrm{~m}$ away from smelters were 2,000 - 10,000 $\mathrm{mg} \cdot \mathrm{kg}^{-1}$ and $2.5-56.5 \mathrm{mg} \cdot \mathrm{kg}^{-1}$, respectively; in the paddy soil about $50 \mathrm{~m}$ away from the smelters the concentrations ranged from 1,100 to $7,000 \mathrm{mg} \cdot \mathrm{kg}^{-1}$ and from 0.5 to 1.3 $\mathrm{mg} \cdot \mathrm{kg}^{-1}$. In the paddy soil $100 \mathrm{~m}$ away from smelters the concentrations were $950-3,600 \mathrm{mg} \cdot \mathrm{kg}^{-1}(\mathrm{~Pb})$ and 0.2 -
$1.5 \mathrm{mg} \cdot \mathrm{kg}^{-1}(\mathrm{Cd})$. In the paddy soil more far away from smelters $(200-300 \mathrm{~m})$, the concentrations were $250-770$ $\mathrm{mg} \cdot \mathrm{kg}^{-1}$ for $\mathrm{Pb}$ and $0.2-1.2 \mathrm{mg} \cdot \mathrm{kg}^{-1}$ for $\mathrm{Cd}$. In general, the $\mathrm{Pb}$ contents in soil decreased with the distance from the smelters but the $\mathrm{Cd}$ content did not always follow the same trend.

The cultivated paddy soil area near the road was used for control. In this case, the assessment method was similar to that used for the soil areas near the smelters. The $\mathrm{Pb}$ and $\mathrm{Cd}$ contents were $55-90 \mathrm{mg} \cdot \mathrm{kg}^{-1}$ and $0.2-1.0 \mathrm{mg} \cdot \mathrm{kg}^{-1}$, these values being higher than those in the garden soils of the households that were not affected by $\mathrm{Pb}$ recycling. This situation can be explained by the effects of traffic activities and agricultural productions. In comparison with the control areas, all the soil samples collected at the paddy soil areas located $20-300 \mathrm{~m}$ far from the smelter had higher concentrations of both heavy metals investigated. This proved that $\mathrm{Pb}$-recycling process caused the increasing of $\mathrm{Pb}$ and $\mathrm{Cd}$ amount in the soil of the surrounding areas.

\section{Table 2. Contents in soils and SPI of Pb and $\mathrm{Cd}$ at study sites in Chi Dao}

\begin{tabular}{|c|c|c|c|c|c|}
\hline \multirow{2}{*}{$\mathbf{N}^{0}$} & \multirow{2}{*}{ Sites } & \multicolumn{2}{|c|}{ Contents (dry weight, $\mathrm{mg} \cdot \mathrm{kg}^{-1}$ ) } & \multicolumn{2}{|c|}{ Soil Pollution Indexes (SPI) } \\
\hline & & $\mathbf{P b}$ & Cd & $\mathbf{P b}$ & Cd \\
\hline \multirow[t]{3}{*}{1} & Soil in village & & & & \\
\hline & - Garden soils of Pb-recycling household & $7,000-15,000$ & $1.8-3.6$ & $10,000-21,400$ & $90-180$ \\
\hline & $\begin{array}{l}\text { - Garden soils of household which are not } \\
\text { affected by } \mathrm{Pb} \text { recycling }\end{array}$ & $40-60$ & $0.5-0.8$ & $57-86$ & $25-40$ \\
\hline 2 & Soil area less than $20 \mathrm{~m}$ away from smelters & $2,000-10,000$ & $2.5-56.5$ & $2,860-14,290$ & $125-2,825$ \\
\hline 3 & Paddy soil $50 \mathrm{~m}$ away from smelters & $1,100-7,000$ & $0.5-1.3$ & $1,570-10,000$ & $25-65$ \\
\hline 4 & Paddy soil $100 \mathrm{~m}$ away from smelters & $950-3,600$ & $0.2-1.5$ & $1,360-5,140$ & $10-75$ \\
\hline 5 & Paddy soil 200-300 m away from smelters & $250-770$ & $0.2-1.2$ & $360-1,100$ & $10-60$ \\
\hline 6 & Control paddy soil area & $55-90$ & $0.2-1.0$ & $80-130$ & $10-50$ \\
\hline 7 & Vietnam standard 7209:2002 & 70 & 2.0 & 100 & 100 \\
\hline 8 & Sediment of ditch & $7000-110,000$ & $3.8-17.7$ & - & - \\
\hline
\end{tabular}

In the water ditch near the smelter area (which was continuously receiving the waste from the $\mathrm{Pb}$-recycling process), the $\mathrm{Pb}$ and $\mathrm{Cd}$ contents in sediment were very high (Pb: 7,000 - 110,000 mg.kg ${ }^{-1}, \mathrm{Cd}: 3.8-17.7 \mathrm{mg} \cdot \mathrm{kg}^{-}$ $\left.{ }^{1}\right)$. This was a dangerous situation because heavy metals could be transferred and accumulated in the paddy soil through dredging and amendment to the field, where the rice and other crops were cultivated. The SPI values showed that the soil in areas affected by Pb-recycling activities was heavily polluted by $\mathrm{Pb}$. The paddy soil around $300 \mathrm{~m}$ away from smelter areas had the SPI from 360 to 10,000 that is $3.6-100$ times higher than the safe level. In case of $\mathrm{Cd}$, only the soil area less than $20 \mathrm{~m}$ around smelters was polluted.

\subsection{Soil pollution in Ha Thuong}

In Ha Thuong, due to Sn-mining operation, there were many fallow soil areas. These were old mine areas (hamlet 4) and paddy soil areas affected by waste 
flowing from ore sift site nearby (hamlet 7), or from mining and sifting area (hamlet 6). The most typical characteristics of the soils in these areas were the low $\mathrm{pH}$ values (3.5 - 4.5, data not shown), the high content in As and $\mathrm{Pb}$ but with $\mathrm{Cd}$ content lower than $1 \mathrm{mg} \cdot \mathrm{kg}^{-1}$ (data not shown). Data from Table 3 show that, among the study sites, the highest As content was found in the grass soil of hamlet $7\left(841-3,809 \mathrm{mg} \cdot \mathrm{kg}^{-1}\right)$, followed by the grass soil of hamlet $4\left(327-1,683 \mathrm{mg} \cdot \mathrm{kg}^{-1}\right)$, while the lowest value was measured in the grass soil of hamlet $6(350-592$ $\mathrm{mg} \cdot \mathrm{kg}^{-1}$, dry weight).

Table 3. Contents in soils and SPI of As at study sites in Ha Thuong (Dang and Chu, 2009)

\begin{tabular}{cl}
$\mathbf{N}^{\mathbf{0}}$ & \multicolumn{1}{c}{ Sites } \\
1 & Grass soil area in hamlet 4 \\
2 & Grass soil area in hamlet 6 \\
3 & Grass soil area in hamlet 7 \\
4 & Vietnam standard $7209: 2002$
\end{tabular}

In fact, the grasses and wild plants that grow at these sites might be a food source for the animals. Therefore, even if these areas are not used for crops cultivating, the potential adverse effects on human and animals are still of concern because the SPI proved that all the study sites were seriously contaminated with As.

In the world, many research results showed similar cases of heavy metals pollution. For example, in China there are over 8,000 national and 230,000 private mining companies operating, resulting in $200,000 \mathrm{~km}^{2}$ of derelict land, which includes the loss of $370,000 \mathrm{hm}^{2}$ of agricultural land (Young, 1998). In a national survey commissioned by the United Kingdom, the Department of the Environment analysed samples collected from November 1981 to June 1982 from 53 locations in England, Scotland, and Wales (Thornton et al., 1990). The results showed that $93 \%$ of the garden soils exceeded 2,000 $\mathrm{mg} \cdot \mathrm{kg}^{-1} \mathrm{~Pb}$. In Derbyshire, the $\mathrm{Pb}$ concentration was within the range of $1,180-22,100 \mathrm{mg} \cdot \mathrm{kg}^{-1}$, while the $\mathrm{Pb}$ concentration in the vegetable plot soil the range was $1,140-26,500 \mathrm{mg} \cdot \mathrm{kg}^{-1}$.

Several studies reported that the $\mathrm{Cd}$ content in soils near the smelter or metallurgical factories were very high. For example, in Poland, at a site located $600 \mathrm{~m}$ away from a $\mathrm{Zn}$ metallurgical factory, the $\mathrm{Cd}$ content in soil was 250 $\mathrm{mg} \cdot \mathrm{kg}^{-1}$ (Greszta and Godzik, 1969). Belgium is an important producer of $\mathrm{Cd}$ (about $25 \%$ of the European production). Certain areas of the country are also polluted by $\mathrm{Cd}$, mainly due to past emissions from non-ferrous industries. $\mathrm{Cd}$ concentration in airborne particles, soil and grass increased through years from 1970 s to $1980 \mathrm{~s}$ (Knetzschmar et al., 1980).

In Vietnam, several scientists investigated the heavy metal contents in soil in several areas (Pham, 2002; Pham et al., 2002; Nguyen, 2003; Tran and Tran, 2002). They found that heavy metals levels were under the safe level according to the Vietnamese standard. However, by using wastewater for the irrigation of crops, the land might have been exposed to heavy metals contamination (Nguyen et al., 2001). According to Le and Nguyen (1998) and to Ho and Nguyen (2003), most of the soil pollutions with $\mathrm{Pb}$ and $\mathrm{Cu}$ are caused by the traditional craft villages and heavy metal recycling activities.

\section{Conclusions}

In Tan Long, the concentrations of $\mathrm{Pb}$ and $\mathrm{Cd}$ in soil samples at almost of all the investigated sites exceeded the limitation level according to the Vietnamese standard, except for the $\mathrm{Pb}$ and $\mathrm{Cd}$ concentrations in the garden soils near the new waste dump and Cd concentration in the soil area adjacent to the new waste dump. In Chi Dao, the $\mathrm{Pb}$ contents in almost of all the soil samples at the investigated sites exceeded the safe level. For $\mathrm{Cd}$, the soils collected from two sites (garden soils of $\mathrm{Pb}$ recycling household and soil area less than $20 \mathrm{~m}$ far from smelters) had the concentrations of $\mathrm{Cd}$ higher than the safe level. The Sn-mining and sifting activities in $\mathrm{Ha}$ Thuong caused a heavy soil pollution with As, in particular the grass soil area in hamlet 7 .

To protect the humans and animals in the investigated areas in the two Northern provinces of Vietnam, Thai Nguyen and Hung Yen, the soil polluted with heavy metals must be urgently remediated. The use of the land surrounding the pollution sources needs to be under the management of the local authorities in order to prevent the food chain from the penetration of heavy metals.

\section{Acknowledgement}

The author would like to thank the Institute of Ecology and Biological Resources at the Vietnam Academy of Science and Technology for the financial support of this study.

\section{References}

[1] Dang, T. A., Chu, T. T. H. 2009. Arsenic contaminated soil in Dai Tu, Thai Nguyen. Vietnam Soil Science Journal 31:60-63 (in Vietnamese)

[2] Dang, T. A., Chu, T. T. H., Dao, T. C. T. 2007. Some characteristics of the flora in $\mathrm{Pb}-, \mathrm{Cd}$-polluted areas in Tan Long, Dong Hy, Thai Nguyen. Proceedings of the $2^{\text {nd }}$ National Scientific Conference on Ecology and Biological Resources, Hanoi 26 October 2007 (Sections of Fauna and Flora of Vietnam \& Ecology and Environment), pp. 297301 (in Vietnamese)

[3] Dang, T. A., Nguyen, P. H., Nguyen, D. T. 2008. Soil pollution with heavy metals in the some areas in Vietnam. Vietnam Soil Science Journal 29:59-62 (in Vietnamese) 
[4] Fleischer, M., Sarofim, A. F., Fassett, D. W., Hammond, P., Shacklette, H. T., Nisbet, L. C. T. and Epstein, S. 1974. Environmental impact of cadmium: A review by the panel on hazardous trace substances. Environmental Health Perspectives 7: 253-323

[5] Geng, C. N., Zhu, Y. G., Tong, Y. P., Smith, S. E., Smith, F.A. 2006. Arsenate (As) uptake by and distribution in two cultivars of winter wheat (Triticum aestivum L.). Chemosphere 62:608-615

[6] Gia Lai Online 2011. http://www.baogialai.com.vn/channel/1604/201106/ 80-benh-tat-o-nguoi-lien-quan-moi-truong-2078208/ (in Vietnamese, retrieved on 2011-11-20)

[7] Greszta, J., Godzik, S. 1969. Effect of zinc metallurgy on soils. Rocz. Gleboznawcze 20(1):195215

[8] Ho, T. L. T., Nguyen, H. T. 2003. Heavy metals status (total and available) of agricultural soil in Van Lam district of Hung Yen province. Vietnam Soil Science Journal 19:167-173 (in Vietnamese)

[9] Knetzschmar, J. G., Delespaul, I., De Rijck, T. 1980. Heavy metal levels in Belgium: a five year survey. Sci. Total Environ. 14:85-97

[10] Lawerys, R., Amery, A., Bernard, A., Bruaux, P., Buchet, J. P., Claeys, F., Plaen, P. D., Ducoffre, G., Fagard, R., Lijnen, P., Nick, L., Roels, H., Rondia, D., Saint-Remy, A., Sartor, F., Staessen, J. 1990. Health effects of environmental exposure to cadmium: Objectives, design and organization of the cadmibel study. Across-sectional morbidity study carried out in Belgium from 1985 to 1989. Environmental Health Perspectives 87:283-289

[11] Le, D., Nguyen, X. C. 1998. Soil polluted by heavy metals in Red river delta. Scientific symposium of University of Science, pp. 193-197 (in Vietnamese)

[12] Nguyen, N. N. 2003. Content micro nutrient and heavy metals in some major soils in the North-East mountainous zone of Vietnam. Vietnam Soil Science Journal 18:15-18 (in Vietnamese)

[13] Nguyen, T. H., Le, T. T., Vu, D. Q. 2001. Study on effect of waster water resources from industry and urban to soil environment in Thanh Tri district. Vietnam Soil Science Journal 14:60-67 (in Vietnamese)

[14] Peng, H. Y., Tian, S. K., Yang, X. E. 2005. Changes of root morphology and $\mathrm{Pb}$ uptake by two species of Elsholtzia under $\mathrm{Pb}$ toxicity. Journal of Zhejiang University Science 6B(6):546-552

[15] Pham, Q. H. 2002. A study of cadmium content in some main soils of Vietnam and norming of soil cadmium contamination. Vietnam Soil Science Journal 16:32-38 (in Vietnamese)

[16] Pham, V. K., Le, T. A., Pham, T. T., Ngo, H. T., Nguyen, N. N., Nguyen, M. K. 2002. The impact of Hanel-Saidong industrial zone on soil and water environment - the problem of heavy metals. Vietnam Soil Science Journal 16:146-149 (in Vietnamese)
[17] Schmoger, M. E. V., Oven, M., Grill, E. 2000. Detoxification of arsenic by phytochelatins in plants. Plant Physiology 122:793-801

[18] Sun, Y., Zhou, Q., Diao, C. 2008. Effects of cadmium and arsenic on growth and metal accumulation of Cd-hyperaccumulator Solanum nigrum L. Bioresource Technology 99(5):1103-1110

[19] Thornton, I., Davies, D. J. A., Watt, J. M. and Quinn, M. J. 1990. Lead exposure in young children from dust and soil in the United Kingdom. Environmental Health Perspectives 89:55-60

[20] Tran, K. T., Tran, K. K. 2002. Heavy metals and other elements in the main soil types in Vietnam. Vietnam Soil Science Journal, 16:13-22 (in Vietnamese)

[21] Viet Bao 2011. http://vietbao.vn/Phong-su/Nguoicuu-lang-chi/ 40022335/263/ (in Vietnamese, retrieved on 2011-11-20)

[22] Vietnam standard 7209:2002. Soil quality Maximum allowable limits of heavy metals in the soil

[23] VnExpress 2011. http://vnexpress.net/gl/xahoi/2001/08/3b9b37c1/ (in Vietnamese, retrieved on 2011-11-20)

[24] Young, K. 1988. Destruction of ecological habitats by mining activities. Agricultural Ecology 16:37-40 